\title{
Deep Venous Thrombosis as a Complication of Brucellosis: A Case Report on Diagnosis and Treatment Management
}

\author{
Bruselloz Komplikasyonu Olarak Derin Venöz Tromboz: Tanı ve Tedavi Yönetimi Üzerine Bir \\ Olgu Sunumu
}

\author{
(1) Tuğba ARSLAN GÜLEN ${ }^{1}$, ๑ Faruk SERHATLIOĞLU², ๑ Ayfer IMRE ${ }^{1}$, ๑ Üner KAYABAŞ ${ }^{1}$ \\ 1 Niğde Ömer Halisdemir University, Faculty of Medicine, Department of Infectious Diseases and Clinical Microbiology, Niğde, Turkey \\ 2Niğde Ömer Halisdemir University, Faculty of Medicine, Department of Cardiovascular Surgery, Niğde, Turkey
}

Keywords: Brucella melitensis, doxycycline, venous thrombosis, drug-drug interaction, rivaroxaban

Anahtar Kelimeler: Brucella melitensis, doksisiklin, venöz tromboz, antibiyoterapi, ilaç-ilaç etkileşimi, rivaroksaban

\section{Dear Editor,}

Brucellosis is one of the most widespread zoonotic diseases. Human brucellosis is common, especially in the Mediterranean region and developing countries ${ }^{[1]}$. Although osteoarticular involvement is common, vascular complications have rarely been associated with brucellosis ${ }^{[2-6]}$. Herein, it is aimed to present a case of human brucellosis complicated by deep venous thrombosis.

A 55-year-old man was admitted to our hospital with a 1-month history of fever and left leg pain associated with swelling and myalgia on April 26, 2017. He had a history of abortion in his sheep and unprotected contact with the birth fluids. The patient had been diagnosed with Brucella infection one week earlier. Rifampicin $600 \mathrm{mg} /$ day per oral and doxycycline $200 \mathrm{mg} /$ day per oral were started as antibiotic therapy.

On physical examination, the patient was febrile, his body temperature was $38{ }^{\circ} \mathrm{C}$, and other vital signs were within normal ranges. His left lower extremity was enlarged, warm, erythematous, and tender. Homan sign was found to be positive on the left leg. Abdominal, cardiopulmonary, and neurological examinations were unremarkable.

No pathological finding was found in other system examinations. The laboratory findings were as follows: white blood cell count
$14,600 / \mu \mathrm{l} \quad(4,000-10,000 / \mu \mathrm{l})$, (neutrophils, 64.5\%), platelet count $440,000 / \mathrm{mm}^{3} \quad\left(150.000-450.000 / \mathrm{mm}^{3}\right)$, erythrocyte sedimentation rate $58 \mathrm{~mm} / \mathrm{h}$, and C-reactive protein was found to be as high as $282 \mathrm{mg} / \mathrm{dl}(0-5 \mathrm{mg} / \mathrm{l})$. Results of the other routine biochemical blood tests (including fibrinogen and D-dimer) were within normal limits. Rose-Bengal slide agglutination test was positive and Wright serum tube agglutination test was positive with a titre of $1 / 640$. Colour venous doppler ultrasound of the left lower extremity revealed that the deep femoral vein, popliteal vein, proximal segments of crural veins, and distal segments of external iliac vein were enlarged and occluded by thrombi. The deep femoral and popliteal veins were enlarged and contained echogenous clots (Figures 1A, 1B). The patient was diagnosed with acute deep venous thrombosis via clinical and radiological findings. Abdominal ultrasound examination was normal. Infective endocarditis was ruled out by normal echocardiography. Protein C level was 87\% (70-140\%), protein S level was 92\% (70-120\%), and tests for autoimmune markers including antinuclear antibody, anti-dsDNA, antineutrophil cytoplasmic antibodies, lupus anticoagulant, and anticardiolipin antibody were negative.

The patient was hospitalised in the department of infectious diseases and clinical microbiology. Rifampicin $600 \mathrm{mg} /$ day per oral, doxycycline $200 \mathrm{mg} /$ day per oral, and streptomycin $1 \mathrm{~g} /$

Cite this article as: Arslan Gülen T, Serhatlıoğlu F, İmre A, Kayabaş Ü. Deep Venous Thrombosis as a Complication of Brucellosis: A Case Report on Diagnosis and Treatment Management. Mediterr J Infect Microb Antimicrob. 2019;8:4. 
day intramuscular were started as antimicrobial treatment. The patient was also started on warfarin sodium $5 \mathrm{mg} /$ day per oral and enoxaparin sodium 0.6 cc subcutaneous twice a day at the same time. Under this anticoagulant and antiaggregant therapy, therapeutic international normalized ratio (INR) could not be achieved. Following consultation, the patient was transferred to the cardiovascular surgery department. Warfarin sodium and enoxaparin sodium were stopped and rivaroxaban, a new generation oral anticoagulant, was started at $20 \mathrm{mg} /$ day. On day 10 of rivaroxaban therapy, colour venous doppler ultrasound revealed regression of the venous thrombi. As the patient's complaints and physical examination findings improved, he was discharged from hospital on the $25^{\text {th }}$ day of his treatment. His prescription was edited as rivaroxaban $20 \mathrm{mg} / \mathrm{day}$, rifampicin $600 \mathrm{mg} / \mathrm{day}$, and doxycycline $100 \mathrm{mg} /$ day, each in oral form. The duration of treatment for brucellosis was extended to three months and rivaroxaban therapy was stopped at the $6^{\text {th }}$ month. At the end of the treatment, the patient was asymptomatic and was completely healthy three month after treatment.

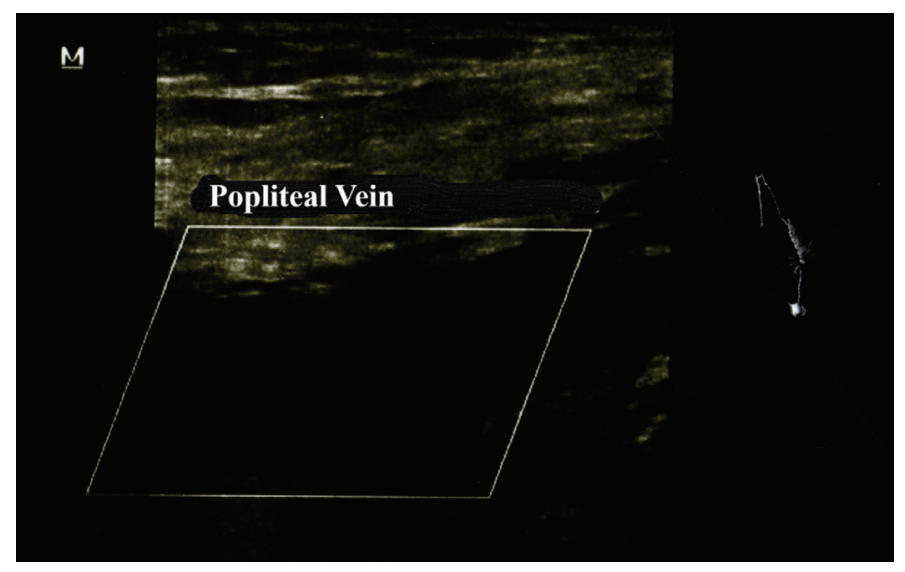

Figure 1. A) Venous doppler ultrasound of left lower extremity: Popliteal vein was contained with echogenous clot

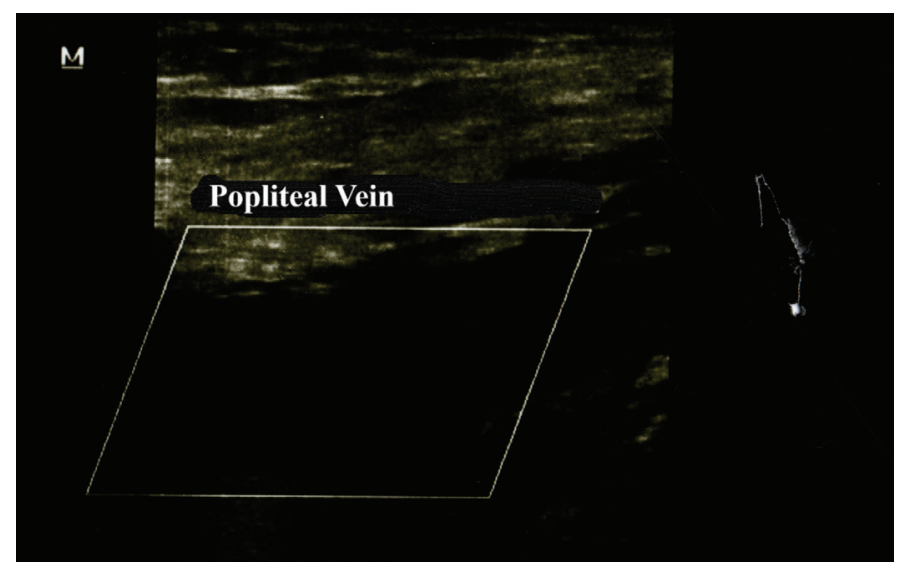

Figure 1. B) Venous doppler ultrasound of left lower extremity: Common femoral vein was enlarged and contained with echogenous clot
Brucellosis is an endemic infectious disease in Turkey, especially in the region of central and eastern Anatolia. Many organ systems may be affected by Brucella infection. Cardiovascular involvement is one of the rare clinical presentations and pericarditis, myocarditis, endocarditis, and vascular involvement have been reported in the literature ${ }^{[2-9]}$. In our patient, deep venous thrombosis was observed and multiple areas of involvement were detected in the vast majority of the vascular system. It was believed that vascular involvement in this case was associated with Brucella infection because there was no risk factor for venous thrombosis, including immobilization, history of previous venous thrombosis, malignancy and chemotherapy, chronic cardiopulmonary diseases, hereditary thrombophilia, obesity, travel history, recent surgical procedure or local tissue trauma. Protein $\mathrm{C}$, protein $\mathrm{S}$, and autoimmune markers were within normal range.

The mechanism of deep venous thrombosis formation, which may coexist with brucellosis, is not clear, but it may be associated with temporary activation of the hypercoagulability cascade, immunological response to Brucella antigen, direct vascular endothelium damage, and granulomatous endophlebitis ${ }^{[3]}$.

Treatment management is important here because rifampicin is metabolized in hepatic cells with cytochrome P450 3A4 oxidase. Cytochrome p450 3A4 is also involved in the metabolism of warfarin. Rifampicin acts as a cytochrome P450 3A4 inducer and induces warfarin metabolism and reduced serum warfarin concentration. Therapeutic INR value was not reached with the combined use of rifampicin and warfarin in this case, leading to the discontinuation of warfarin and initiation of rivaroxaban, which is a more reliable anticoagulant. Rivaroxaban is an oral, direct factor Xa inhibitor that targets free and clot-bound factor $\mathrm{Xa}$ and factor $\mathrm{Xa}$ in the prothrombinase complex. Rivaroxaban does not inhibit cytochrome P450 enzymes or known drug transporter systems and, since rivaroxaban has multiple elimination pathways, it has no clinically relevant interaction with most commonly prescribed medications ${ }^{[10]}$.

In conclusion, brucellosis should be considered and excluded in patients presenting with venous thrombosis, especially in endemic areas. Additionally, drug-drug interactions are important in the management of treatment, and medications should be carefully selected and monitored.

\section{Ethics}

Peer-review: Externally and internally peer-reviewed.

\section{Authorship Contributions}

Surgical and Medical Practices: T.A.G., F.S., Concept: T.A.G., F.S., Ü.K., Design: T.A.G., F.S., A.I., Data Collection or Processing: T.A.G., 
F.S., Analysis or Interpretation: T.A.G., A.I., Literature Search: T.A.G., Writing: T.A.G., F.S.

Conflict of Interest: No conflict of interest was declared by the authors.

Financial Disclosure: The authors declared that this study received no financial support.

\section{References}

1. Ariza J, Bosilkovski M, Cascio A, Colmenero JD, Corbel MJ, Falagas ME, Memish ZA, Roushan MR, Rubinstein E, Sipsas NV, Solera J, Young EJ, Pappas G; International Society of Chemotherapy; Institute of Continuing Medical Education of loannina. Prospectives for the Treatment of Brucellosis in the 21st Century: The loannina Recommendations. PLoS Med. 2007;4:e317.

2. Tolaj I, Mehmeti M, Ramadani H, Tolaj J, Dedushi K, Fejza H. Brucellosis Associated with Deep Vein Thrombosis. Infect Dis Rep. 2014;6:5441.

3. Davoudi AR, Tayebi A, Najafi N, Kasiri E. Deep vein thrombosis as a rare complication of brucellosis. Caspian J Intern Med. 2014;5:127-9.
4. Koubaa M, Frigui M, Cherif Y, Jallouli M, Kaddour N, Jemaa MB, Bahloul Z. Deep vein thrombosis associated with acute brucellosis: a case report and review of the literature. Korean J Intern Med. 2013;28:628-30.

5. Salihi S, Andaç Ş, Kalender M, Yıldırım O, İmre A. Simultaneous acute deep vein thrombosis and acute brucellosis. A case report. Kardiochir Torakochirurgia Pol. 2016;13:162-3.

6. Hachfi W, Bellazreg F, Atig A, Lasfar NB, Kaabia N, Letaief A. Splenic Infarction Associated with Acute Brucellosis: A Case Report, Advances in Infectious Diseases. 2012:4;89-91.

7. Zorlu G, Uyar S, Ozer H, Esin M, Kir S, Tokuc A, Dolu, Bostan F, Cekin AH. A case of brucellosis with a rare complication: pericarditis. Eur J Case Rep Intern Med. 2017;4:000471.

8. Abid L, Frikha Z, Kallel S, Chokri Z, Ismahen B, Amin B, Hammami R, Abid D, Akrout M, Hentati M, Kammoun S. Brucella myocarditis: a rare and lifethreatening cardiac complication of brucellosis. Intern Med. 2012;51:901-4.

9. Gatselis NK, Makaritsis KP, Gabranis I, Stefos A, Karanikas K, Dalekos GN. Unusual cardiovascular complications of brucellosis presenting in two men: two case reports and a review of the literature. J Med Case Rep. 2011;5:22.

10. Mueck W, Stampfuss J, Kubitza D, Becka M. Clinical Pharmacokinetic and Pharmacodynamic Profile of Rivaroxaban. Clin Pharmacokinet. 2014;53:1-16. 